\title{
The role of limiting sodium intake in the diet - from theory to practice
}

\section{Rola ograniczenia spożycia sodu w diecie - od teorii do praktyki}

\author{
Stanisław Surma ${ }^{1}$ (D), Monika Romańczyk ${ }^{1}$, Edward Bańkowski \\ ${ }^{1}$ Faculty of Medical Sciences in Katowice, Medical University of Silesia in Katowice, Poland \\ ${ }^{2}$ Department of Medical Biochemistry, Medical University of Bialystok, Poland
}

\begin{abstract}
Sodium is the main extracellular cation. In recent years, many mechanisms that have been involved in the regulation of sodium metabolism have been described, such as interstitial tissue and glycosaminoglycans, Th17 lymphocytes and interleukin 17, epithelial sodium channel, glycocalyx and proprotein converting enzyme subtilisin/kexin type 6. Complexity of homeostasis mechanisms sodium makes it an interest in modern pharmacology. The described mechanisms somewhat explain the sodium sensitivity phenomenon occurring in a significant proportion of patients with arterial hypertension.

Processed foods are the main source of salt in the diet. The food processing process is associated with a significant increase in the salt content of these products. Excessive salt intake in the diet is observed in most countries of the world. The relationship between excessive salt intake in the diet and the occurrence of diseases such as hypertension, stroke, stomach cancer, left ventricular hypertrophy, urolithiasis and others has been the subject of numerous studies. Numerous benefits of reducing salt in the diet have been demonstrated.
\end{abstract}

Key words: sodium, salt, cardiovascular disease

Folia Cardiologica 2020; 15, 3: 227-235

\section{Sodium metabolism in the human body}

Sodium is the main extracellular cation in the human body. Its total body content is approx. $4200 \mathrm{mmol}(60 \mathrm{mmol} / \mathrm{kg}$ body weight). As much as $91 \%$ of total sodium in the human body is found in the extracellular space, where it reaches a concentration of 135-145 mmol/L. The intracellular space contains $9 \%$ of total sodium in the human body, and its concentration is $10-20 \mathrm{mmol} / \mathrm{L}$ $[1,2]$. Nearly $1 / 3$ of total sodium in the body (approx. $20 \mathrm{mmol} / \mathrm{kg}$ body weight) is poorly exchangeable or not exchangeable, and it is mostly located in the bones. The remaining amount of sodium (approx. $40 \mathrm{mmol} / \mathrm{kg}$ body weight) is mainly located in the extracellular space, and it is well exchangeable [1-3].

Sodium supplied with food is mostly absorbed in the middle and further part of the small intestine. In case of preserved sodium homeostasis, as much as $95 \%$ of sodium ingested with food is excreted through the kidneys, $4.5 \%$ through the digestive tract and $0.5 \%$ through the skin [2]. A number of mechanisms are involved in the regulation of sodium metabolism. The most important ones include: renin-angiotensin-aldosterone system, reduction of sodium charge reaching the macula densa in the distal convoluted tubule of the nephron, natriuretic peptide system, pressure natriuresis as well as hypercalcaemia and hypokalaemia [4]. 


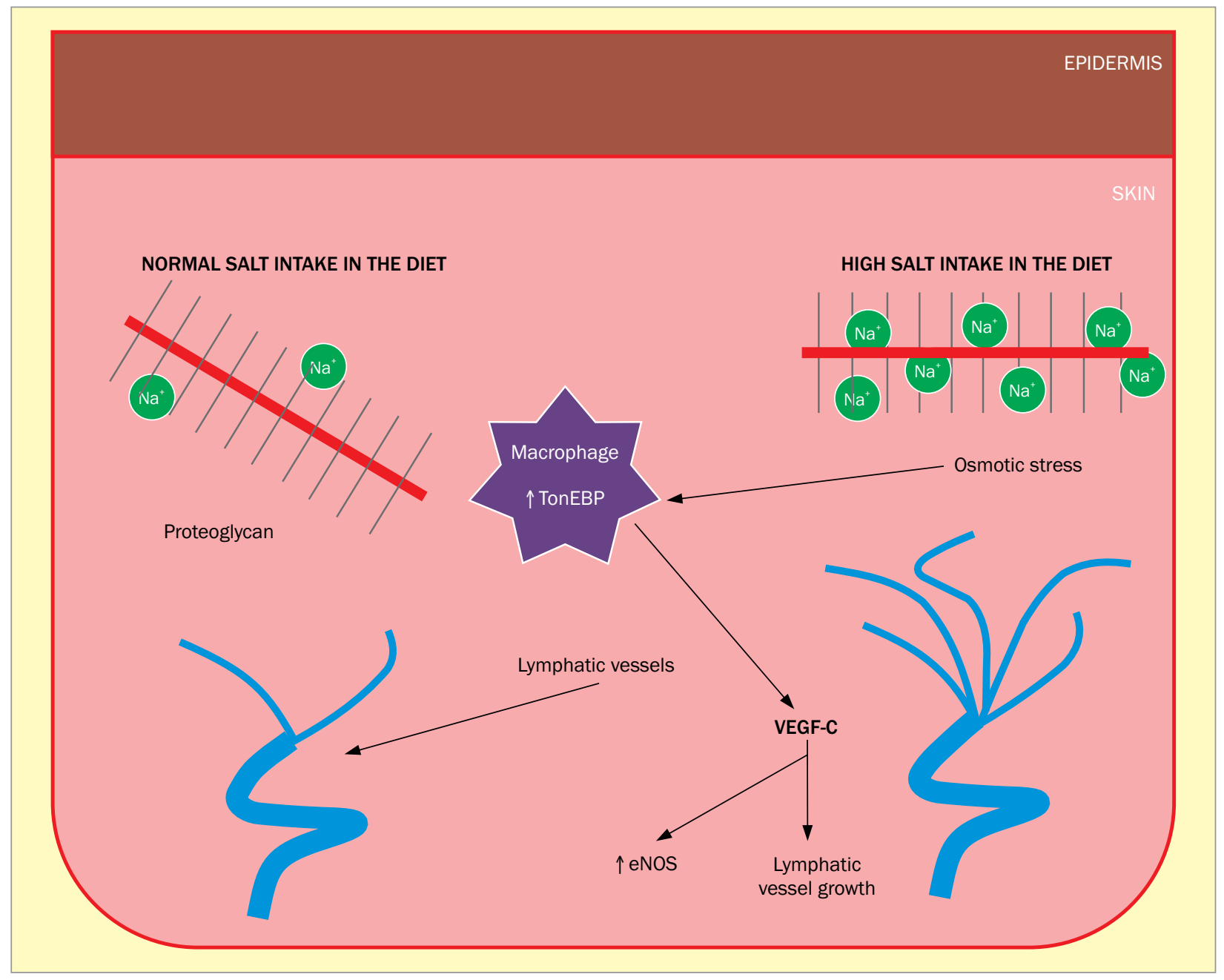

Figure 1. Involvement of the interstitial tissue in the regulation of sodium metabolism (based on [10]); TonEBP - tonicity enhancer binding protein; VEGF-C - vascular endothelial growth factor C; eNOS - endothelial nitric oxide synthase

\section{Regulation of sodium metabolism - selected mechanisms}

\section{Subcutaneous connective tissue - glycosaminoglycans}

For many years it has been believed that the sodium concentration in the extracellular extravascular fluid compartment (i.e. interstitial fluid compartment) does not differ much from the sodium concentration in the plasma. Small differences in the sodium concentration between these compartments were explained by significantly higher concentrations of proteins in the blood plasma than in the interstitial fluid compartment, which was justified in the Gibbs-Donnan effect [5].

An important role of subcutaneous tissue in the regulation of sodium metabolism has been described in recent years [6]. In the interstitial fluid compartment, especially in the subcutaneous tissue, there are a lot of glycosaminoglycans (GAGs) forming proteoglycans of the connective tissue. GAGs are involved in the storage of sodium in the subcutaneous tissue (Figure 1) [6,7]. Sodium accumulated in the interstitial tissue is inactive osmotically, as a result of which it does not affect the water retention by the kidneys [7].

An increased sodium concentration in the interstitial tissue stimulates the inflow of macrophages (MPS, mononuclear phagocyte phagocyte system cells) into this space. Under the influence of local hypernatraemia, these cells activate the expression of the tonicity enhancer binding protein (TonEBP) gene, which is a transcription factor $[7,8]$. The protein stimulates the expression of the vascular endothelial growth factor $C$ gene (VEGF-C) and increases its secretion by MPSs. The main effects of VEGF-C are: activation of lymphangiogenesis, angiogenesis, sodium clearance from the interstitial tissue through the stimulation of sodium bonding by GAGs and generation of nitric oxide. The VEGF-C gene performs these functions through two membrane receptors. The activation of 
vascular endothelial growth factor receptor 3 (VEGFR-3) leads to the above-mentioned lymphangiogenesis and angiogenesis and to GAGs being transported with lymph. The activation of the vascular endothelial growth factor receptor 2 (VEGFR-2 receptor) stimulates vascular endothelial cells to the above-mentioned synthesis of nitric oxide (the VEGF-C gene activates the endothelial nitric oxide synthase). The bonding between sodium and GAGs leads to their osmotic immobilisation $[6,9,10]$. It was demonstrated that during a diet rich in sodium hypertension was more common in animals in which macrophages were destroyed as a result of the administration of liposomes with clodronate [9].

The above-mentioned phenomena related to the accumulation of sodium ions by GAGs in the subcutaneous tissue and the involvement of the immune system in this process were also demonstrated in humans. Selvarajah et al. [11] showed that the skin can buffer sodium provided in the diet, reducing the haemodynamic effects of an increased sodium content in the body. This effect was more visible in men, which indicates that gender affects the ability of the subcutaneous tissue to immobilise sodium [11]. The method used to locate osmotically inactive sodium is ${ }^{23} \mathrm{Na}^{+}-\mathrm{MRI}[12]$.

Taking the above-mentioned data into account, it can be concluded that sodium can be accumulated not only in the osmotically active form, increasing the volume of extracellular fluid (according to the Guyton's hypothesis), but also in the osmotically inactive form associated with GAGs. Moreover, the immune system also has a significant effect on the regulation of sodium metabolism through the formation of new lymphatic vessels, thanks to which GAGs are extracted from the skin along with sodium [10].

It is also worth noting that the above mechanisms that form the signalling pathway TonEBP-VEGF-C-VEGFC-R-NO-lymphangiogenesis and angiogenesis may explain different levels of sensitivity to sodium supplied with diet, expressed by changes in blood pressure (sodium sensitivity). Sodium sensitivity is defined as a change in blood pressure of at least $10 \mathrm{~mm} \mathrm{Hg}$ in response to a 4-hour infusion of $2,000 \mathrm{~mL}$ of $\mathrm{NaCl}$ compared to the blood pressure measured after following a low-sodium diet (10-20 mmol $\mathrm{NaCl} /$ day) for several days [13]. Sodium sensitivity occurs in $30-50 \%$ of patients with hypertension and $20-30 \%$ of patients with normal blood pressure, which indicates that it is a significant clinical problem [14]. In conclusion, it can be stated that sodium-dependent blood pressure (sodium-dependent hypertension) may result from reduced interstitial volume in the scope of the osmotic inactivation of sodium (as well as an impaired normal immobilisation of sodium in the interstitium), whereas sodium-independent hypertension may be the result of increased volume in the scope of the inactivation of sodium ions by the interstitial tissue [10].
There is also another practical conclusion to be drawn from this discussion. It is not possible to predict an increase in natraemia in patients with hyponatraemia during corrective treatment based on the knowledge of the size of fluid compartments in the body. In such patients, the ability of the interstitial tissue to immobilise sodium may vary. Therefore, to avoid the phenomenon of overcorrection, the most severe complication of which is pontine demyelination syndrome, it is necessary to determine natraemia as often as possible during corrective treatment [3].

\section{Th17 lymphocytes and interleukin 17}

The results of some tests on animals indicate that Th17 lymphocytes, which produce interleukin 17 (IL-17), are attracted to the interstitial tissue by GAGs combined with sodium ions. Interleukin 17 has hypertensive properties by increasing the stiffness of the vascular endothelium $[15,16]$.

Increased salt intake in the diet leads to an increase in the number of Th17 lymphocytes and reduces the number of Lactobacillus murinus in the human gut microbiota. Based on the studies, it was demonstrated that the administration of probiotics with Lactobacillus murinus reduces the occurrence of sodium-dependent increase in blood pressure and in the number of Th17 lymphocytes [17]. An excessive amount of salt leads to a reduction in the number of Lactobacillus murinus, as a result of which the amount of indole compounds decreases. A reduced concentration of these compounds leads to the stimulation of the differentiation of T lymphocytes into Th17 lymphocytes. These lymphocytes secrete the above-mentioned IL-17, which, on the one hand, intensifies the reabsorption of sodium from the intestines and, on the other hand, damages the vascular endothelium (impaired vasodilatory properties). Both mechanisms increase blood pressure [18]. It was shown that an increased amount of salt in the diet can also increase the number of Th17 lymphocytes by activating the antigen-presenting cells (APC). As a result of the stimulation of APC, IL-23, IL-6 and IL-1 are secreted, which stimulate T lymphocytes to secrete IL-17 and other proinflammatory cytokines. The above-mentioned phenomena lead to the inflammation of the kidneys and blood vessels, which in turn contributes to the development of hypertension [19].

The study results indicate that Th17 lymphocytes, interleukin 17 and gut microbiota, the composition of which depends on the diet, has a significant impact on the regulation of sodium metabolism [20].

\section{Epithelial sodium channel (ENaC) and glycocalyx}

Increased sodium intake in the diet leads to the activation of the sympathetic nervous system, which results, for instance, in the activation of the renin-angiotensin-aldosterone system [21]. By affecting the mineralocorticoid 


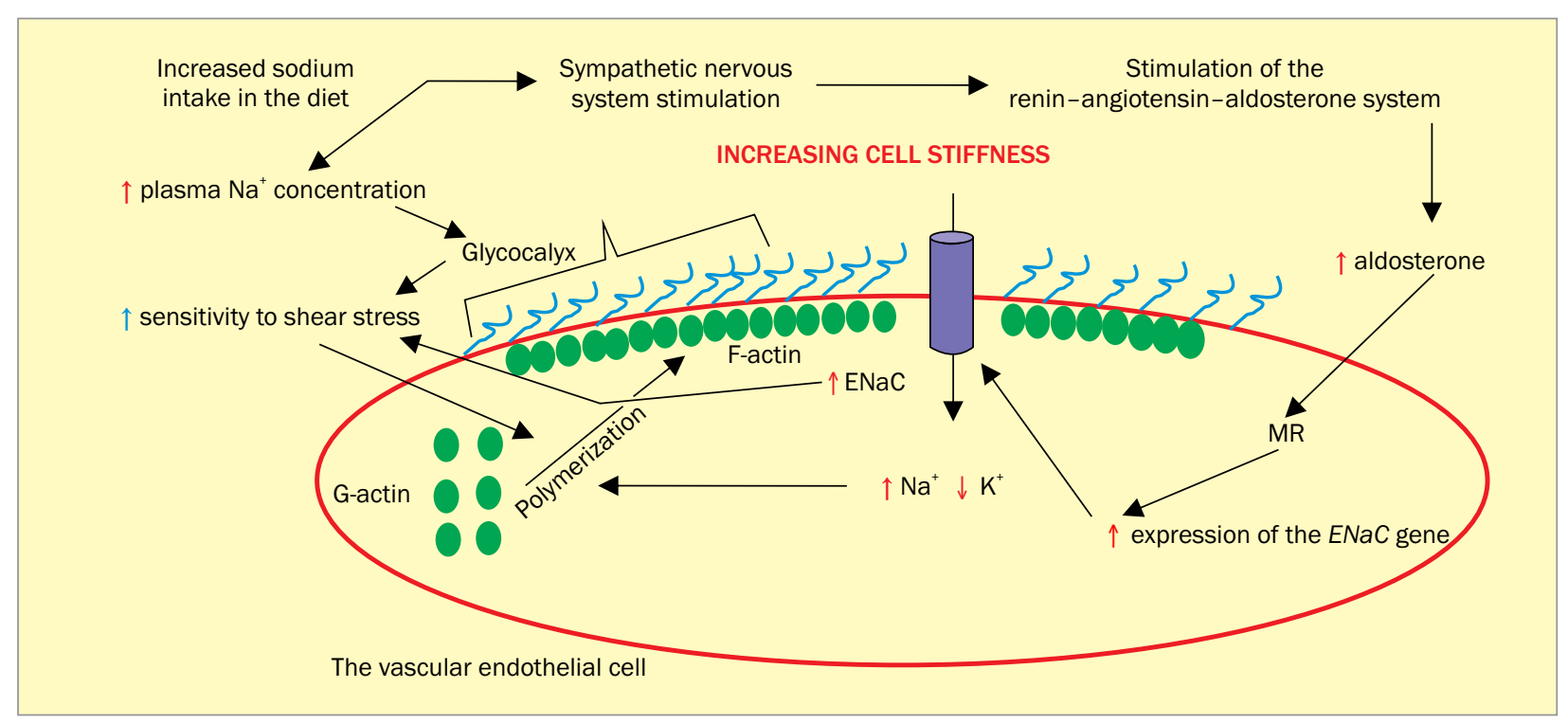

Figure 2. Effects of increased sodium intake in the diet on vascular endothelial cells; $\mathrm{Na}^{+}-$sodium; $\mathrm{ENaC}$ - epithelial sodium channel; $\mathrm{K}^{+}$- potassium; MR - mineralocorticoid receptor

receptor (MR), aldosterone increases the gene expression for the epithelial sodium channel (ENaC) [22]. Increased sodium intake in the diet can also increase the MR activity by increasing the activity of protein Rac1 (MR activity modulator). It has been demonstrated that an increased activity of Rac1 may lead to the development of sodium-dependent hypertension [23]. An increase in the amount of ENaC on the surface of vascular endothelial cells increases the sensitivity of these cells to shear stress exerted by bloodstream. The ENaC channel combines with globular actin (G-actin) leading to its polymerisation and the creation of filamentous actin (F-actin). Filamentous actin increases the stiffness of the shell of vascular endothelial cells, resulting in an increase in the total peripheral resistance (TPR), which is an important determinant of blood pressure (Figure 2) [24].

The more $\mathrm{ENaC}$ is found in the membrane of vascular endothelial cells, the more sensitive to shear stress and the stiffer these cells are. An additional factor stimulating the change in actin conformation is the change in glycocalyx conformation (decrease in its height and increase in the stiffness) of vascular endothelial cells. The factors changing the glycocalyx conformation are shear stress and direct toxic effects of sodium (already in the concentration found in the plasma $>139 \mathrm{mmol} / \mathrm{L}$, i.e. within the normal range) $[25,26]$. Glycocalyx and $\mathrm{ENaC}$ are therefore shear stress sensors (Figure 2). Moreover, an increase in the intracellular concentration of sodium ions with a simultaneous decrease in the concentration of potassium ions is another factor activating the polymerisation of $\mathrm{G}$ actin into $\mathrm{F}$ actin (this is an important mechanism because in Poland people consume an excessive amount of salt and a low amount of potassium in their diet) (Figure 2). An increased stiffness of the shell of endothelial cells reduces the activity of nitric oxide synthase and reduces the sensitivity of these cells to NO [27]. In contrast to sodium, an increased serum concentration of potassium reduces the stiffness of endothelial cells and increases the release of NO [28, 29]. According to Oberleithner et al. [24]: 1) there is a negative correlation between the "stiffness" of vascular endothelial cells and the activity of endothelial nitric oxide synthase; 2) an increase in the concentration of sodium in the plasma significantly increases the stiffness of vascular endothelial cells (in the presence of aldosterone and $\mathrm{ENaC}$ ); 3) an increase in potassium in the plasma reduces the stiffness of vascular endothelial cells and increases the activity of endothelial nitric oxide synthase only in the case of low sodium concentrations in the plasma.

In conclusion, it can be stated that an increased sodium intake in the diet has a negative effect on the vascular endothelial function by stimulating the sympathetic nervous system and the renin-angiotensin-aldosterone system, and by changing the glycocalyx conformation. All these processes lead to an increased stiffness of vascular endothelial cells, which directly results in increased blood pressure. It should be emphasised that increased sodium intake directly impairs normal endothelial function, which in turn results in increased blood pressure in the mechanism independent of the volume status.

\section{Proprotein convertase subtilisin/kexin type 6 (PCSK6)}

Proprotein convertase subtilisin/kexin type 6 (PCSK6) is a serine protease involved in the activation of corrin. Corrin 


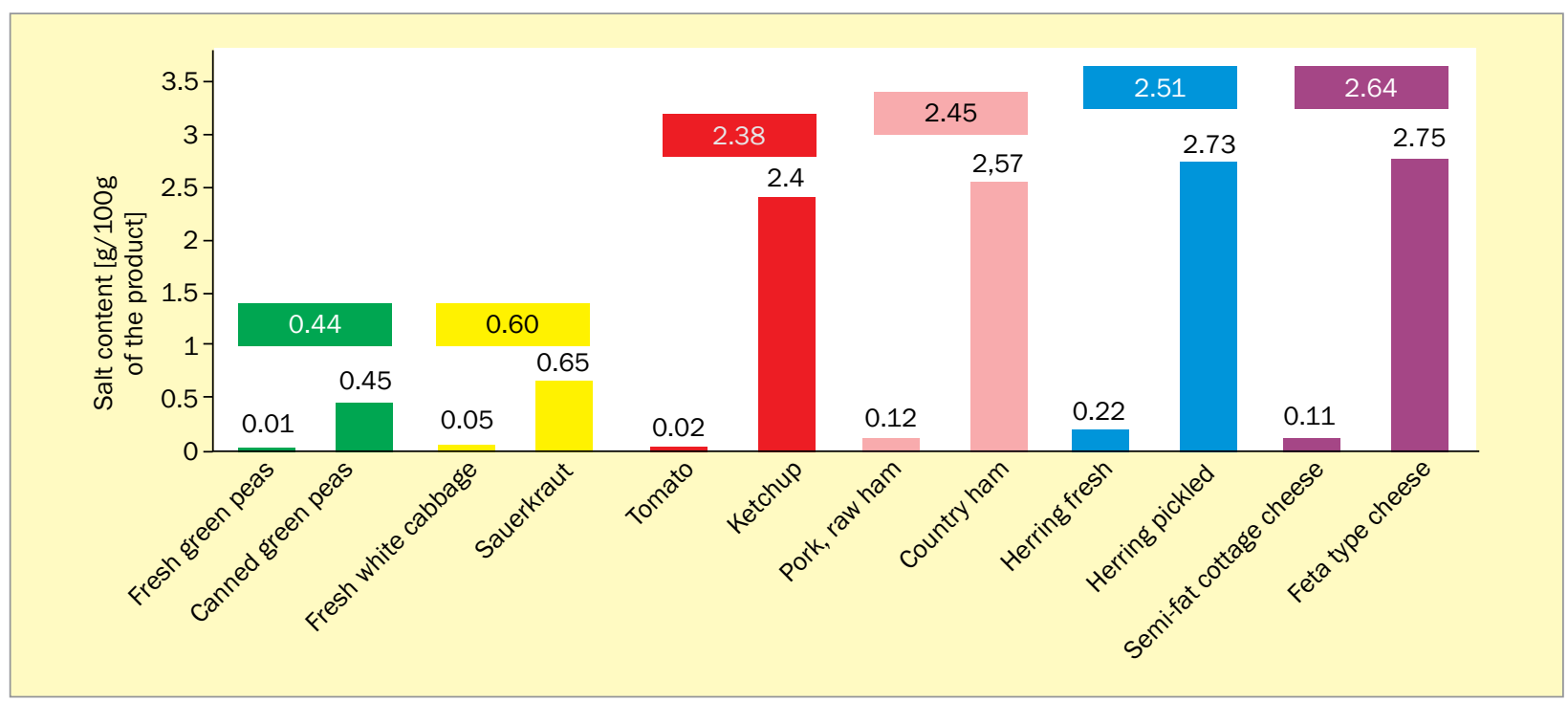

Figure 3. Salt content in selected fresh and processed products. The difference in salt content in products ( $\mathrm{g} / 100 \mathrm{~g}$ of the product) is given in rectangles (based on [31, 33])

is an enzyme necessary for the formation of a biologically active atrial natriuretic peptide (ANP). The PCSK6 gene mutation leads to sodium-dependent hypertension. Experimental studies have shown that the use of benzamidine (serine protease inhibitor) led to the inhibition of corrin activation. The PCSK6 gene mutation leads to a decrease in the secretion of ANP, which in consequence impairs the excretion of excessive sodium from the body and increases natraemia. Increased natraemia in turn leads to an increase in the volume status and blood pressure [30].

The above-mentioned mechanisms regulating sodium metabolism, which have been described relatively recently, show us the complexity of sodium homeostasis. It can be expected that the above-mentioned elements of the regulation of sodium metabolism will be the subject of further experimental and clinical studies and that they may become be a new possible target for drug therapy of hypertension and other cardiovascular diseases in the future.

\section{Sources of sodium in the diet}

Sodium is a natural ingredient of food of animal and plant origin. It is used in the form of table salt $(\mathrm{NaCl})$ during seasoning and adding salt to meals. Moreover, it is an important ingredient added to processed food to extend its shelf-life [31].

According to the European Society of Cardiology (ESC), the sources of salt in everyday diet include processed products (72\%), salt added during cooking (20\%) and salt contained in water and drugs (8\%) [32]. It is worth noting that we may directly affect only $20 \%$ of all salt sources in our diet [32].
According to other authors, processed food products are the source of not $72 \%$ but $85 \%$ of the daily amount of salt in the diet [31, 33].

A high salt content is typical of fast-food products. A typical fast-food lunch set consisting of a hamburger, chips and sauce (usually ketchup) contains $4.5 \mathrm{~g}$ of salt, which is as much as $90 \%$ of the daily recommended intake (DRI). Kebab, which is another popular fast-food product, contains about 4.0 to $8.4 \mathrm{~g}$ of salt, while pizza 7.0 to $12.8 \mathrm{~g}$ of $\mathrm{NaCl}$. It is also worth mentioning the so-called instant soups which contain even up to $4.1 \mathrm{~g}$ of salt [34-37]. One slice of white or wholegrain bread contains about $0.5 \mathrm{~g}$ of $\mathrm{NaCl}$ [38].

The Institute of Food and Nutrition in Warsaw has prepared a report comparing salt content in fresh products and their processed equivalents (Figure 3).

As can be seen in Figure 3, The processing of food involves a significant increase in its salt content [31, 33].

\section{Salt consumption in Poland and Europe}

Studies carried out by Eaton and Konner have shown that the ancestors of man consumed food with a salt content not exceeding $1 \mathrm{~g} /$ day. These observations indicate that man is evolutionarily adapted to a diet considered now to be low sodium $[39,40]$.

Currently, the average consumption of sodium in the world is about $3.95 \mathrm{~g} /$ day, i.e. about $10 \mathrm{~g}$ of $\mathrm{NaCl}$ ( $1 \mathrm{~g}$ of $\mathrm{NaCl}$ contains $0.4 \mathrm{~g}$ of sodium). Salt consumption varies in European countries (Figure 4) [41].

As far as the consumption of salt in Poland, especially by men, is concerned, our country ranks high compared to other EU countries [41]. 


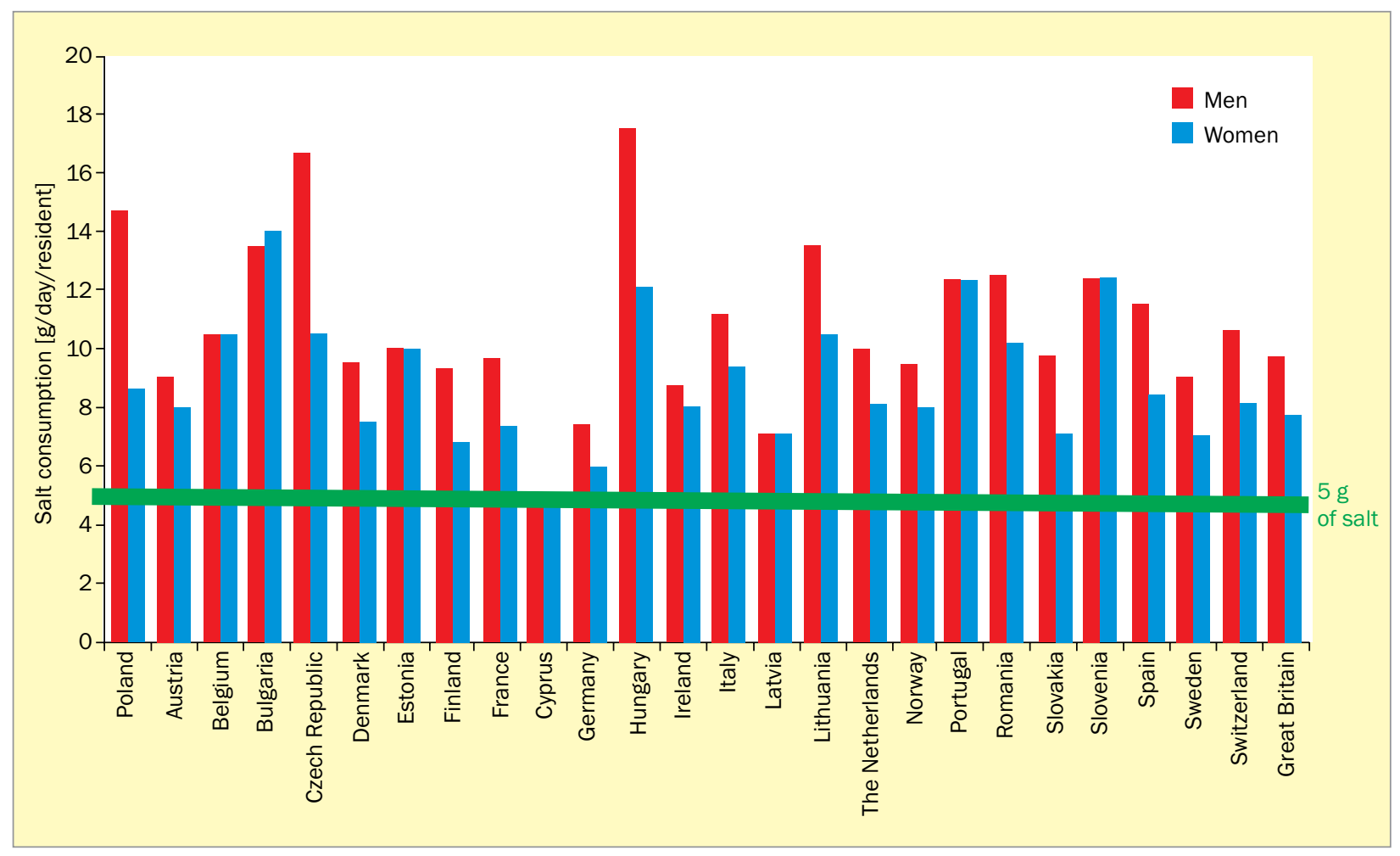

Figure 4. Average salt consumption in Poland and in Europe (g/day/resident) (based on [41])

In Central and Eastern Asia and Western Europe, the average sodium intake is $>4.2 \mathrm{~g} /$ day ( $>10.5 \mathrm{~g} \mathrm{NaCl} /$ day). In North America, Western Europe as well as Australia and New Zealand, the average sodium intake varies between 3.4 to $3.8 \mathrm{~g} /$ day ( 8.5 to $9.5 \mathrm{~g} \mathrm{NaCl} /$ day), whereas in Sub-Saharan Africa and Central America, it is $<3.3 \mathrm{~g} /$ /day (< 8.25 g NaCl/day) [42].

\section{Salt consumption and cardiovascular diseases}

According to Mozzaffarian et al., 1.65 million deaths from cardiovascular diseases per year all over the world are associated with excessive sodium consumption: $61.9 \%$ of these deaths occurred in men and $38.1 \%$ in women. These deaths represented almost 1 in 10 deaths from cardiovascular diseases (9.5\%) [43].

\section{Arterial hypertension}

The risk of cardiovascular disease increases with an increase in blood pressure. Evidence derived from many different studies confirms a direct correlation between salt consumption and blood pressure. The INTERSALT Study (International Study of Electrolyte Excretion and Blood Pressure) was one of the first observational studies on salt intake and blood pressure. The study included 10,074 women and men from 32 countries. Sodium excretion was measured based on the 24-hour urine collection. A clear correlation was observed between daily sodium intake and systolic blood pressure [44]. Taking the above results into account, it was decided to check whether limited sodium intake in the diet would result in the decrease in blood pressure. The DASH-Sodium Study (Dietary Approaches to Stop Hypertension - Sodium Study), conducted in the United States on a group of 412 patients with prehypertension or stage-1 hypertension, was the flagship study evaluating this phenomenon. The subjects were randomly assigned to follow the DASH diet, i.e. the so-called healthy diet (low in salt), and the typical American diet (rich in salt). It was observed that the systolic blood pressure in patients with both prehypertension and stage-1 hypertension decreased by $11.5 \mathrm{~mm} \mathrm{Hg}$ on average, which corresponds to the administration of one antihypertensive drug [45].

The meta-analysis of 126 intervention studies with the participation of patients with hypertension, carried out by Graudal et al. [46] showed that limited salt intake in the diet leads to a decrease in systolic and diastolic blood pressure. It should be mentioned that the race of the subjects did not affect the observed effect [46]. It is also worth pointing out that limited salt intake in the diet may help to control resistant hypertension [47]. The TONE (Trial of Nonpharmacologic Interventions in the Elderly) study assessed the effect of limiting the dietary sodium intake ( $<80 \mathrm{mmol} /$ day) in hypertensive patients treated with a single antihypertensive drug. After 3 months an attempt was made to stop antihypertensive treatment. The attempt was successful for $30 \%$ of the patients [48]. 
In conclusion, it should be stated that any limitation of table salt intake in the diet has a beneficial effect on both the risk of developing, and the treatment of, hypertension.

\section{Other cardiovascular diseases}

An increase of $5 \mathrm{~g} /$ day in salt intake involves a 17-percent higher risk of cardiovascular disease and a 23-percent higher risk of stroke. Finland has been striving to reduce the intake of salt in the diet since the 1970s. For more than 30 years of taking preventive action, Finland has managed to reduce its salt intake by one third ( $6 \mathrm{~g} /$ day). Systolic blood pressure decreased by over $10 \mathrm{~mm} \mathrm{Hg}$ on average and mortality from stroke and ischaemic heart disease fell by $75-80 \%$, whereas life expectancy increased by $5-6$ years $[49,50]$. Similar preventive measures have also been taken in Japan. Over the decade, salt intake in this country has fallen from $13.5 \mathrm{~g} /$ day to $12.1 \mathrm{~g} /$ day. It was associated with a significant decrease in stroke mortality $[49,50]$.

Left ventricular hypertrophy is an important risk factor for premature failure of this organ. Regardless of blood pressure, salt intake is a risk factor for left ventricular hypertrophy. It has been shown that limited salt intake in the diet leads to the regression of left ventricular hypertrophy [51]. Moreover, limited dietary salt intake seems to normalise glomerular hyperfiltration, which often precedes the development of hypertension, observed in sodium-sensitive individuals [52].

Excessive salt intake is also a risk factor for other diseases (Table 1).

\section{Recommendations for limiting salt intake in the diet}

In the guidelines published in 2018 , the Polish Society of Hypertension recommends to limit the intake of table salt from the usual amount of 9-12 $\mathrm{g}$ of $\mathrm{NaCl}$ to less than $5 \mathrm{~g}$ of $\mathrm{NaCl}(2 \mathrm{~g} \mathrm{Na}) /$ day. This recommendation concerns both patients with hypertension and those who want to lead a healthy lifestyle [53]. It is worth mentioning that $5 \mathrm{~g}$ of table salt is the equivalent of one teaspoon. Salt intake in Poland and Europe significantly exceeds the recommended amount of $5 \mathrm{~g} /$ day (Figure 4 - green line) [41].

The Institute of Food and Nutrition in Warsaw symbolically crosses out the salt shaker on the Pyramid of Healthy Nutrition and Physical Activity and proposes several ways to reduce the intake of salt in the diet, such as: limiting the amount of salt added during meal preparation or, if necessary, adding salt at the end of cooking, using fresh or dried herbs instead of salt, using potassium sodium salt (a mixture of $\mathrm{KCl}$ and $\mathrm{NaCl}$ ) and choosing products with a lower salt content (DRI, daily recommended intake - \%) [54].

A study carried out on the veterans living in Taiwan (2.5-year observation) showed that a $17 \%$ reduction in the
Table 1. Impact of excessive salt intake in the diet on human health (based on [50])

$\begin{array}{lc}\text { Clinical situation/disease } & \text { Reliability of evidence* } \\ \text { Arterial hypertension } & ++++ \\ \text { Stroke } & +++ \\ \text { Cardiovascular diseases } & +++ \\ \text { Left ventricular hyper- } & +++ \\ \text { trophy } & \\ \text { Glomerular hyperfiltration } & +++ \\ \text { Kidney stone } & +++ \\ \text { Calcium excretion } & ++++ \\ \text { Bone demineralization } & ++ \\ \text { Bone fractures } & + \\ \text { Stomach cancer } & ++ \\ \text { Liquid retention } & ++++ \\ \text { in the body } & \\ \text { Cataract } & + \\ \text { Bronchial asthma } & + \\ \text { Meniere's disease } & + \\ \text { *Based on the arbitrarily adopted Cappucio's scale } & \end{array}$

use of $\mathrm{NaCl}$ along with a $76 \%$ increase in the intake of $\mathrm{KCl}$ in the diet reduced the risk of death from cardiovascular diseases by $40 \%$ [55].

\section{Conclusion}

The article presents the elements of the regulation of sodium metabolism that have been discovered only recently and that are of interest to modern pharmacology; they show how complex maintaining the homeostasis of this ion in the body is. These mechanisms also explain, in a way, the phenomenon of sodium sensitivity occurring in a considerable number of people. As shown by the research, eating habits associated with the consumption of table salt lead to the development of hypertension, cardiovascular and many other diseases resulting in many premature deaths. The consumption of salt in Poland still significantly exceeds $5 \mathrm{~g}$ recommended by the Polish Society of Hypertension. Most of salt in an average diet comes from processed foods (72-85\%). The Institute of Food and Nutrition in Warsaw recommends several ways that will help people limit the intake of salt in the diet. Special attention is drawn to the use of potassium sodium salt.

\section{Conflict of interest}

Authors do not declare the conflict of interest. 


\section{Streszczenie}

Sód jest głównym kationem zewnątrzkomórkowym. W ostatnich latach opisano wiele mechanizmów biorących udział w regulacji gospodarki sodowej, takich jak: tkanka śródmiąższowa i glikozaminoglikany, limfocyty Th17 i interleukina 17, nabłonkowy kanał sodowy, glikokaliks oraz proproteinowa konwertaza subtyliziny/kexiny typu 6. Złożoność mechanizmów homeostazy gospodarki sodowej sprawia, że budzi ona zainteresowanie nowoczesnej farmakologii. Opisane mechanizmy poniekąd tłumaczą zjawisko sodowrażliwości występujące u znacznej części chorych z nadciśnieniem tętniczym.

Głównym źródłem soli w diecie są pokarmy przetworzone. Proces przetwarzania pokarmów wiąże się z znacznym wzrostem zawartości soli w tych produktach. Nadmierne spożycie soli w diecie obserwuje się w większości krajów świata. Związek między nadmiernym spożyciem soli w diecie a występowaniem chorób, takich jak nadciśnienie tętnicze, udar mózgu, rak żołądka, przerost lewej komory serca, kamica moczowa i inne, był przedmiotem licznych badań. Wykazano liczne korzyści płynące z ograniczenia soli w diecie.

Słowa kluczowe: sód, sól, choroby układu krążenia

Folia Cardiologica 2020; 15, 3: 227-235

\section{References}

1. Surma S, Adamczak M, Więcek A. Hiponatremia spowodowana tiazydowymi i tiazydopodobnymi lekami moczopędnymi. Terapia. 2019; 10(381): 4-10.

2. Hyla-Klekot L, Kokot F. Nerkowa regulacja gospodarki sodowej. Nefrol Dial Pol. 2010; 14(2): 59-62.

3. Spasovski G, Vanholder R, Allolio B, et al. Clinical practice guideline on diagnosis and treatment of hyponatraemia. Nephrol Dial Transplant. 2014; 29(2): 1-39, doi: 10.1093/ndt/gfu050, indexed in Pubmed: 24569496.

4. Esteva-Font C, Ballarin J, Fernández-Llama P. Molecular biology of water and salt regulation in the kidney. Cell Mol Life Sci. 2012; 69(5): 683-695, doi: 10.1007/s00018-011-0858-4, indexed in Pubmed: 21997386.

5. Kokot F. Gospodarka wodno-elektrolitowa i kwasowo-zasadowa w stanach fizjologii i patologii. Wydanie VI. Wydawnictwo Lekarskie PZWL, Warszawa 2005.

6. Titze J, Machnik A. Sodium sensing in the interstitium and relationship to hypertension. Curr Opin Nephrol Hypertens. 2010; 19(4): 385-392, doi: 10.1097/MNH.0b013e32833aeb3b, indexed in Pubmed: 20571401.

7. Titze J. Water-free sodium accumulation. Semin Dial. 2009; 22(3): 253-255, doi: 10.1111/j.1525-139X.2009.00569.x, indexed in Pubmed: 19573004.

8. Kokot F, Hyla-Klekot L. Sodium sensors of the matrix of the interstitial fluid space and endothelial vascular cells - role in the extrarenal regulation of sodium metabolism and blood pressure. Arterial Hypertens. 2011; 15(1): 1-4.

9. Machnik A, Neuhofer W, Jantsch J, et al. Macrophages regulate saltdependent volume and blood pressure by a vascular endothelial growth factor-C-dependent buffering mechanism. Nat Med. 2009; 15(5): 545-552, doi: 10.1038/nm.1960, indexed in Pubmed: 19412173.

10. Selvarajah V, Connolly K, McEniery C, et al. Skin sodium and hypertension: a paradigm shift? Curr Hypertens Rep. 2018; 20(11): 94, doi: 10.1007/s11906-018-0892-9, indexed in Pubmed: 30215153.

11. Selvarajah V, Mäki-Petäjä KM, Pedro L, et al. Novel mechanism for buffering dietary salt in humans: effects of salt loading on skin sodium, vascular endothelial growth factor $\mathrm{C}$, and blood pressure. Hypertension. 2017; 70(5): 930-937, doi: 10.1161/HYPERTENSIONAHA.117.10003, indexed in Pubmed: 28974570.
12. Titze J. Sodium balance is not just a renal affair. Curr Opin Nephrol Hypertens. 2014; 23(2): 101-105, doi: 10.1097/01. mnh.0000441151.55320.c3, indexed in Pubmed: 24401786.

13. Weinberg MH, Miller JZ, Luft FC, et al. Definition and characterictics of sodium sen-sivity and blood pressure resistance. Hypertension. 1986; 8(6 Pt 2): II127-II134, doi: 10.1161/01.hyp.8.6_pt_2.ii127, indexed in Pubmed: 3522418.

14. He FJ, MacGregor GA. Reducing population salt intake worldwide: from evidence to implementation. Prog Cardiovasc Dis. 2010; 52(5): 363-382, doi: 10.1016/j.pcad.2009.12.006, indexed in Pubmed: 20226955.

15. Machnik A, Dahlmann A, Kopp C, et al. Mononuclear phagocyte system depletion blocks interstitial tonicity-responsive enhancer binding protein/vascular endothelial growth factor $\mathrm{C}$ expression and induces salt-sensitive hypertension in rats. Hypertension. 2010; 55(3): 755-761, doi: 10.1161/HYPERTENSIONAHA.109.143339, indexed in Pubmed: 20142563.

16. Guzik TJ, Hoch NE, Brown KA, et al. Role of the T cell in the genesis of angiotensin II induced hypertension and vascular dysfunction. J Exp Med. 2007; 204(10): 2449-2460, doi: 10.1084/jem.20070657, indexed in Pubmed: 17875676.

17. Wilck N, Matus MG, Kearney SM, et al. Salt-responsive gut commensal modulates T17 axis and disease. Nature. 2017; 551(7682): 585-589, doi: 10.1038/nature24628, indexed in Pubmed: 29143823.

18. Wyatt CM, Crowley SD. Intersection of salt- and immune-mediated mechanisms of hypertension in the gut microbiome. Kidney Int. 2018; 93(3): 532-534, doi: 10.1016/j.kint.2018.01.001, indexed in Pubmed: 29475542.

19. Park JS, Oh Y, Park O, et al. PEGylated TRAIL ameliorates experimental inflammatory arthritis by regulation of Th17 cells and regulatory $T$ cells. J Control Release. 2017; 267: 163-171, doi: 10.1016/j.jconrel.2017.10.004, indexed in Pubmed: 29017854.

20. Smiljanec K, Lennon SL. Sodium, hypertension, and the gut: does the gut microbiota go salty? Am J Physiol Heart Circ Physiol. 2019; 317(6): H1173-H1182, doi: 10.1152/ajpheart.00312.2019, indexed in Pubmed: 31585045.

21. Adamczak M, Ritz E. Endogenne steroidy kardiotoniczne - oubaina, imarinobuf-agenina a nadciśnienie tętnicze. Postępy w nefrologii i nadciśnieniu tętniczym. Medycyna Praktyczna, Kraków 2008. 
22. Fuller PJ, Young MJ. Mechanisms of mineralocorticoid action. Hypertension. 2005; 46(6): 1227-1235, doi: 10.1161/01. HYP.0000193502.77417.17, indexed in Pubmed: 16286565.

23. Yoshida S, Ishizawa K, Ayuzawa N, et al. Local mineralocorticoid receptor activation and the role of Rac1 in obesity-related diabetic kidney disease. Nephron Exp Nephrol. 2014; 126(1): 16-24, doi: 10.1159/000358758, indexed in Pubmed: 24603367.

24. Oberleithner $\mathrm{H}$, Kusche-Vihrog $\mathrm{K}$, Schillers $\mathrm{H}$. Endothelial cells as vascular salt sensors. Kidney Int. 2010; 77(6): 490-494, doi: 10.1038/ /ki.2009.490, indexed in Pubmed: 20054292.

25. Callies C, Fels J, Liashkovich I, et al. Membrane potential depolarization decreases the stiffness of vascular endothelial cells. J Cell Sci. 2011; 124(Pt 11): 1936-1942, doi: 10.1242/jcs.084657, indexed in Pubmed: 21558418.

26. Fels J, Jeggle P, Liashkovich I, et al. Nanomechanics of vascular endothelium. Cell Tissue Res. 2014; 355(3): 727-737, doi: 10.1007/ /s00441-014-1853-5, indexed in Pubmed: 24643677.

27. Oberleithner $\mathrm{H}$, Riethmüller $\mathrm{C}$, Schillers $\mathrm{H}$, et al. Plasma sodium stiffens vascular endothelium and reduces nitric oxide release. Proc Natl Acad Sci USA. 2007; 104(41): 16281-16286, doi: 10.1073/ /pnas.0707791104, indexed in Pubmed: 17911245.

28. Li J, White J, Guo L, et al. Salt inactivates endothelial nitric oxide synthase in endothelial cells. J Nutr. 2009; 139(3): 447-451, doi: 10.3945/jn.108.097451, indexed in Pubmed: 19176751.

29. Oberleithner $\mathrm{H}$, Callies $\mathrm{C}$, Kusche-Vihrog $\mathrm{K}$, et al. Potassium softens vascular endothelium and increases nitric oxide release. Proc Natl Acad Sci USA. 2009; 106(8): 2829-2834, doi: 10.1073/ /pnas.0813069106, indexed in Pubmed: 19202069.

30. Shenghan C, Pengxiu C, Ningzheng D, et al. PCSK6-mediated corin activation is es-sential for normal blood pressure. Nat Med. 2015; 21(9): 1048-1053, doi: 10.1038/nm.3920, indexed in Pubmed: 26259032.

31. Adamczak M, Sabiak-Błaż N, Ritz E. Sól a nadciśnienie tętnicze. In: Więcek A, Kokot F. ed. Postępy w nefrologii i nadciśnieniu tętniczym. Tom IX. Medycyna Praktyczna, Kraków 2010: 11-17.

32. https://www.escardio.org/Journals/E-Journal-of-Cardiology-Practice/ Nolume-10/How-to-quantify-salt-intake-in-certain-patients (April 20, 2020).

33. https://ncez.pl/abc-zywienia-/zasady-zdrowego-zywienia/zawartosc-soli-w-produktach-spozywczych- (April 20, 2020).

34. Jeżewska M, Kulczak M, Błasińska I. Zawartość soli w wybranych koncentratach obi-adowych. Bromat Chem Toksykol. 2011; 3: 585-590.

35. Jaworowska A, Blackham T, Stevenson L, et al. Determination of salt content in hot takeaway meals in the United Kingdom. Appetite. 2012; 59(2): 517-522, doi: 10.1016/j.appet.2012.06.018, indexed in Pubmed: 22772043.

36. Mojska H, Świderska K. Zawartość soli w produktach fast food w Polsce. Cz.1. Frytki ziemniaczane. Żyw Człow. 2011; 38(6): 449-456.

37. Tabela wartości odżywczych. http://www.mcdonalds.pl (April 20, 2020).

38. www.zdrowie.med.pl (April 20, 2020).

39. Eaton SB, Konner M. Paleolithic nutrition. A consideration of its nature and current implications. N Eng| J Med. 1985; 312(5): 283-289, doi: 10.1056/NEJM198501313120505, indexed in Pubmed: 2981409.

40. Eaton SB, Eaton SB. Paleolithic vs. modern diets - selected pathophysiological implications. Eur J Nutr. 2000; 39(2): 67-70, doi: 10.1007/ /s003940070032, indexed in Pubmed: 10918987.

41. Heerspink HJL, Navis G, Ritz E. Salt intake in kidney disease a missed therapeutic opportunity? Nephrol Dial Transplant. 2012;
27(9): 3435-3442, doi: 10.1093/ndt/gfs354, indexed in Pubmed: 22942175.

42. Powles J, Fahimi S, Micha R, et al. Global Burden of Diseases Nutrition and Chronic Diseases Expert Group (NutriCoDE). Global, regional and national sodium intakes in 1990 and 2010: a systematic analysis of $24 \mathrm{~h}$ urinary sodium excretion and dietary surveys worldwide. BMJ Open. 2013; 3(12): e003733, doi: 10.1136/bmjopen-2013-003733, indexed in Pubmed: 24366578.

43. Mozaffarian D, Fahimi S, Singh GM, et al. Global Burden of Diseases Nutrition and Chronic Diseases Expert Group. Global sodium consumption and death from cardiovascular causes. N Engl J Med. 2014; 371(7): 624-634, doi: 10.1056/NEJMoa1304127, indexed in Pubmed: 25119608.

44. Stamler J. The INTERSALT Study: background, methods, findings, and implications. Am J Clin Nutr. 1997; 65(2 Suppl): 626S-642S, doi: 10.1093/ajcn/65.2.626S, indexed in Pubmed: 9022559.

45. He F, MacGregor G. Effect of longer-term modest salt reduction on blood pressure. Cochrane Database Syst Rev. 2004, doi: 10.1002/14651858.cd004937.

46. Graudal NA, Hubeck-Graudal T, Jürgens G. Effects of low-sodium diet vs. high-sodium diet on blood pressure, renin, aldosterone, catecholamines, cholesterol, and triglyceride (Cochrane Review). Am J Hypertens. 2012; 25(1): 1-15, doi: 10.1038/ajh.2011.210, indexed in Pubmed: 22068710.

47. Pimenta E, Gaddam KK, Oparil S, et al. Effects of dietary sodium reduction on blood pressure in subjects with resistant hypertension: results from a randomized trial. Hypertension. 2009; 54(3): 475-481, doi: 10.1161/HYPERTENSIONAHA.109.131235, indexed in Pubmed: 19620517.

48. Whelton PK, Appel LJ, Espeland MA, et al. Sodium reduction and weight loss in the treatment of hypertension in older persons: a randomized controlled trial of nonpharmacologic interventions in the elderly (TONE). TONE Collaborative Research Group. JAMA. 1998; 279(11): 839-846, doi: 10.1001/jama.279.11.839., indexed in Pubmed: 9515998.

49. Cappuccio FP, Capewell S, Lincoln P, et al. Policy options to reduce population salt intake. BMJ. 2011; 343: d4995, doi: 10.1136/bmj. d4995, indexed in Pubmed: 21835876.

50. Cappuccio FP. Cardiovascular and other effects of salt consumption. Kidney Int Suppl (2011). 2013; 3(4): 312-315, doi: 10.1038/kisup.2013.65, indexed in Pubmed: 25019010.

51. Schmieder RE, Langenfeld MR, Schmieder RE, et al. Sodium intake modulates left ventricular hypertrophy in essential hypertension. J Hypertens Suppl. 1988; 6(4): S148-S150, doi: 10.1097/00004872198812040-00043, indexed in Pubmed: 2977158.

52. Barba G, Cappuccio FP, Russo L, et al. Renal function and blood pressure response to dietary salt restriction in normotensive men. Hypertension. 1996; 27(5): 1160-1164, doi: 10.1161/01.hyp.27.5.1160, indexed in Pubmed: 8621211.

53. Tykarski A, Filipiak K, Januszewicz A, et al. Wytyczne PTNT. Zasady postępowania w nadciśnieniu tętniczym 2019. Arterial Hypertens. 2019; 23(2): 41-87, doi: 10.5603/ah.a2019.0008.

54. Jarosz M, Szponar L, Rychlik E, Wierzejska E. Woda i elektrolity. In: Jarosz M. ed. Normy żywienia dla populacji polskiej - nowelizacja. Instytut Żywności i Żywienia, Warszawa 2012: 143-153.

55. Chang HY, Hu YW, Yue CSJ, et al. Effect of potassium-enriched salt on cardiovascular mortality and medical expenses of elderly men. Am J Clin Nutr. 2006; 83(6): 1289-1296, doi: 10.1093/ajcn/83.6.1289, indexed in Pubmed: 16762939. 